\title{
Postępy w leczeniu chorych na przewlekłą białaczkę szpikową
}

\section{Advances in therapy of patients with chronic myelogenous leukemia}

\author{
Tomasz Sacha, Joanna Wącław \\ Katedra Hematologii, Collegium Medicum, Uniwersytet Jagielloński, Kraków
}

\begin{abstract}
Streszczenie
Wyniki badań klinicznych nad skutecznościq inhibitorów kinaz tyrozynowych (TKI) II generacji $w$ porównaniu z imatynibem zastosowanych $w$ pierwszym rzucie leczenia chorych na przewlekta biataczke szpikowa (CML) wskazuja na ich większa skuteczność we wczesnym osiaganiu gtęokich odpowiedzi molekularnych — kluczowego kryterium kwalifikacji do badan nad zaprzestaniem leczenia, w większym stopniu obniżaja także ryzyko progresji do fazy akceleracji lub kryzy blastycznej. Ich podawanie $w$ I linii leczenia nie wiaze sie natomiast $z$ przedtużeniem przeżycia catkowitego w porównaniu z leczeniem imatynibem. Znacznie poprawity sie wyniki leczenia chorych opornych na stosowane dotychczas TKI za sprawa zarejestrowanego inhibitora III generacji - ponatynibu - aktywnego także u chorych z mutacja T315I. Stosowanie tego leku wymaga jednak ostrożności ze względu na istniejacy profil toksyczności i ryzyko wywotywania niedrożności naczyń tętniczych $i$ żylnych. Wyniki badań nad zaprzestaniem leczenia TKI sugeruja, że możliwe jest uzyskanie dtugotrwatej odpowiedzi wolnej od konieczności ponownego wdrożenia terapii (TFR) u cześci chorych z gtęboka odpowiedzia molekularna. Trwaja badania nad określeniem optymalnej dtugości czasu poprzedzajacego leczenie TKI, pozostawania w odpowiedzi molekularnej, jej gtębokości oraz biomarkerów stużacych identyfikacji grupe z największa szansa na dtugotrwata TFR. Dodatkowe zaburzenia cytogenetyczne, tak zwane major route, redukcje ilości transkryptu BCR/ABL1 do mniej niz 10\% po 3 i do mniej niż 1\% po 6 miesiacach leczenia TKI oraz czas 50-procentowej redukcji ilości transkryptu BCR/ABL1 zidentyfikowano jako nowe czynniki prognostyczne. Analiza danych ze szwedzkiego rejestru chorych na CML potaczonego z rejestrem chorych na nowotwory wskazuje, że u chorych na CML leczonych TKI istnieje o $50 \%$ wyższe ryzyko rozwoju wtórnych nowotworów niz $w$ zdrowej populacji.
\end{abstract}

Słowa kluczowe: przewlekła białaczka szpikowa, inhibitory kinaz tyrozynowych, czynniki rokownicze, wyleczenie

Hematologia 2015; 6, 1: 63-69

\begin{abstract}
Clinical trials suggest that patients treated up-front with second generation tyrosine kinase inhibitors (TKI) have increased chances for achieving rapid and deep molecular responses to therapy; this being a key criterion for discontinuation studies, thus reducing the risk of progression to accelerated phase or blast crisis as compared to imatinib. To date however, outcomes for all second generation TKIs are no different in overall survival than to imatinib. On the other hand administering ponatinib, a third generation TKI, demonstrates improved outcomes in patients resistant
\end{abstract}

Adres do korespondencji: Tomasz Sacha, Katedra Hematologii, Collegium Medicum, Uniwersytet Jagielloński, ul. Kopernika 17, 31-501 Kraków, tel. 1242476 00, faks 1242474 26, e-mail: sachatom@gmail.com 
to other TKI therapies including those with the T315I ABL mutation, however this drug should be used with caution due to its toxicity profile and the risks of blood clots and occluded arteries and veins. Prospective trials suggest that TKI therapy may be safely and successfully discontinued leading to durable treatment-free remission (TFR) in a proportion of CML patients with deep and sustained molecular responses. Yet to be determined from ongoing studies, are the optimal durations of initial TKI therapy and deep molecular responses before TKI cessation, together with those biomarkers identifying patients with the highest chances of achieving prolonged TFR. Novel prognostic factors were found to be major-route, 'additional cytogenic aberrations' detected at diagnosis, reduced $B C R / A B L 1$ transcript levels to $<10 \%$ at 3 months and to $<1 \%$ at 6 months along with the BCR/ABL1 transcript level halving time. Data analysis from cross linking patients from the Swedish CML register with the Swedish Cancer Register indicates that CML patients have a $50 \%$ increased risk of developing a second malignancy compared to a normal control population.

Key words: chronic myelogenous leukemia, tyrosine kinase inhibitors, prognostic factors, cure

Hematologia 2015; 6, 1: 63-69

\section{Wprowadzenie}

Zastosowanie w leczeniu chorych na przewlekłą białaczkę szpikową (CML, chronic myelogenous leukemia) inhibitorów kinaz tyrozynowych (TKI, tyrosine kinase inhibitors) znacząco zmieniło nie tylko rokowanie u chorych na CML, ale także cele leczenia oraz oczekiwania zarówno pacjentów, jak i lekarzy. U pacjentów, którzy otrzymywali imatynib w dawce $400 \mathrm{mg} /$ dobę w ramach badania IRIS (International Randomized Study of Interferon Vs STI571) po 8 latach tego badania stwierdza się długotrwałą odpowiedź hematologiczną i cytogenetyczną, niewielki odsetek progresji do fazy akceleracji (AP, accelerated phase) lub kryzy blastycznej (BP, blastic phase) i wieloletnie przeżycia. Odsetek przeżycia całkowitego (OS, overall survival) u chorych otrzymujących imatynib wynosi $85 \%$, a $93 \%$, jeśli brane pod uwagę są wyłącznie zgony spowodowane progresją CML i te, do których doszło przed przeszczepieniem allogenicznych krwiotwórczych komórek macierzystych [1].

Wieloletnie doświadczenia w leczeniu chorych na CML za pomocą TKI wskazują, że dla optymalnego wyniku terapii i zminimalizowania ryzyka progresji do AP lub BP niezwykle istotne jest jak najwcześniejsze osiagnięcie całkowitej odpowiedzi cytogenetycznej (CCyR, complete cytogenetic response), większej odpowiedzi molekularnej (MMR, major molecular response), a uzyskanie głębokich odpowiedzi molekularnych $\left(\mathrm{MR}^{4}\right.$, molecular response $4 \log$ lub $\mathrm{MR}^{4,5}$, molecular response 4,5 log) stwarza szansę na bezpieczne zaprzestanie leczenia. Taka strategia jest ważna nie tylko $z$ ekonomicznego punktu widzenia, ale także bezpieczeństwa chorych, które przewiduje maksymalne wydłużenie czasu przeżycia przy minimalnym ryzyku zachorowania na wtórne nowotwory.

\section{Inhibitory kinaz tyrozynowych II i III generacji}

Wyniki randomizowanych badań 3. fazy nad skutecznością TKI II generacji (2GTKI, second-generation $T K I$ ) stosowanych w pierwszym rzucie leczenia u chorych na CML w fazie przewlekłej (CP, chronic phase) - DASISION (Dasatinib versus Imatinib Study in Treatment-Naive CML Patients) oraz ENESTnd (Evaluating Nilotinib Efficacy and Safety in Clinical Trials of Newly Diagnosed Ph+ CML patients) - wykazały większe skumulowane odsetki uzyskiwanych odpowiedzi (CCyR, MMR, $\mathrm{MR}^{4}$ i MR $^{4,5}$ ) u chorych otrzymujących 2 GTKI niż u pacjentów leczonych imatynibem [2, 3]. Lepsze wyniki leczenia za pomocą 2 GTKI uzyskiwano we wszystkich grupach zaawansowania choroby według wskaźnika Sokala. Zarówno dazatynib, jak i nilotynib lepiej niż imatynib zapobiegały progresji do AP lub BP, nie zaobserwowano natomiast istotnych różnic w odsetkach OS i przeżycia wolnego od progresji (PFS, progression-free survival) w grupach pacjentów leczonych dazatynibem lub nilotynibem w porównaniu $z$ leczonymi imatynibem.

Podobne wyniki (większe odsetki odpowiedzi molekularnej po roku leczenia u chorych otrzymujących dazatynib i porównywalne odsetki OS i PFS po średnim okresie obserwacji 34 miesięcy) uzyskano u chorych leczonych dazatynibem lub imatynibem w ramach badania SPIRIT2 [4]. Wyniki randomizowanego badania nad skutecznością bosutynibu - kolejnego 2GTKI stosowanego $\mathrm{w}$ pierwszym rzucie leczenia chorych na CML 
— nie wykazały istotnych różnic w odsetkach CCyR osiągniętych po 12 miesiącach leczenia; odnotowano natomiast istotnie większy odsetek MMR osiągniętych w 12. miesiącu leczenia, zaś czas konieczny do uzyskania CCyR oraz MMR był krótszy. Podobnie jak w przypadku innych 2GTKI, bosutynib skuteczniej niż imatynib zapobiegał transformacji do AP i BP. We wrześniu 2012 roku amerykańska Agencja ds. Żywności i Leków (FDA, Food and Drug Administration) zarejestrowała bosutynib do leczenia chorych na CML w $\mathrm{CP}$ (CP-CML), AP (AP-CML) i BP (BP-CML) u chorych opornych lub nietolerujących wcześniejszego leczenia TKI [5].

Oporność na leczenie imatynibem i 2GTKI była powodem opracowania i badań klinicznych nad ponatynibem - TKI III generacji, który hamuje kinazę BCR/ABL1, FLT3, FGFR oraz VEGFR także w komórkach zawierających mutację genu $B C R / A B L 1$ o typie T315I wywołującej całkowitą oporność na stosowane uprzednio TKI. Opublikowane wyniki badania 1 . fazy PACE obejmujące chorych na CP-CML, AP-CML i BP-CML, a także chorych na ostrą białaczkę limfoblastyczną (ALL, acute lymphoblastic leukemia) z chromosomem Filadelfia (Ph, Philadelphia) (ALL $\mathrm{Ph}+)$ - opornych lub nietolerujących dazatynibu lub nilotynibu albo posiadających mutację T315I - wskazywały na dobrą tolerancję i wysoką skuteczność tego leku [6]. W grudniu 2012 roku ponatynib uzyskał rejestrację do leczenia chorych na CML i ALL $\mathrm{Ph}+$ opornej na pozostałe TKI; lek zarejestrowano na podstawie wyników uzyskanych u chorych, u których w $91 \%$ przypadków stosowano dwa lub więcej TKI, a 51\% otrzymało wszystkie trzy inhibitory (imatynib, dazatynib, nilotynib). Całkowitą odpowiedź hematologiczną (CHR, complete hematologic response) uzyskało $98 \%$ chorych, większą odpowiedź cytogenetyczną (MCyR, major cytogenetic response) - $72 \%$, a $44 \%$ osiągnęło MMR. W grupie chorych z mutacją T315I wszyscy uzyskali CHR, a $92 \%$ osiągnęło MCyR, natomiast u chorych bez wykrywalnej mutacji CHR i MCyR uzyskano odpowiednio u 100\% i $62 \%$ pacjentów [6]. Natomiast rekrutacja do badania klinicznego EPIC dotyczącego ponatynibu w leczeniu pierwszego rzutu u chorych na CP-CML została wstrzymana (18.10.2013 r.) decyzją FDA $z$ powodu akumulacji poważnych działań niepożądanych w postaci niedrożności naczyń tętniczych i żylnych, które wystąpiły u $18 \%$ chorych; niedrożności naczyń wieńcowych, mózgowych oraz naczyń obwodowych odpowiednio u 6,7\%, 5,6\% i 5,1\% chorych, a naczyń żylnych u $4,5 \%$ chorych [7].

\section{Zaprzestanie leczenia za pomocą TKI a trwałość remisji CML}

Możliwość bezpiecznego odstawienia TKI u chorych na CML było w ostatnich latach przedmiotem kilku publikacji zawierających raporty z badań nad tym zagadnieniem. Wyniki badania STIM (STop IMatinib) sugerowały, że możliwe jest utrzymanie całkowitej remisji molekularnej (CMR, complete molecular response) u części chorych, u których odstawiono imatynib. Przedstawiono wyniki 100 pacjentów z CMR utrzymującą się przynajmniej przez 2 lata; ponowne pojawienie się transkryptu $B C R / A B L 1$ odnotowano u 42 spośród $69(61 \%)$ pacjentów z przynajmniej 12-miesięcznym czasem obserwacji (średnia 24 miesiące) [8]. Wyniki analizy wielowariantowej dowiodły, ze czynnikami ryzyka nawrotu molekularnego były płeć żeńska, krótszy niż 5 lat okres leczenia imatynibem i wysoki wskaźnik Sokala w chwili rozpoznania. Do nawrotu molekularnego, poza jednym przypadkiem, doszło w okresie do 7 miesięcy po odstawieniu imatynibu. Co bardzo istotne, wszyscy pacjenci odzyskali utraconą odpowiedź po ponownym wdrożeniu leczenia.

Wyniki powyższej próby klinicznej były inspiracją do opracowania przez ELN (European LeukemiaNet) protokołu badania EURO-SKI (EURO-SKI, Europe Stop Kinase Inhibitors), za cel którego przyjęto określenie przeżycia wolnego od nawrotu molekularnego po odstawieniu TKI (I lub II generacji) u osób pozostających przez minimum rok $\mathrm{w} \mathrm{MR}^{4}$ uzyskanej w przebiegu przynajmniej 3-letniego leczenia za pomocą TKI. Ocena 2-letniego przebiegu obserwacji prowadzonej w ramach tego badania u 200 chorych wskazuje, że przeżycie wolne od utraty MMR w 6. miesiącu po zaprzestaniu leczenia (czas, w którym nawrót występuje u ok. $90 \%$ pacjentów) wynosi $61 \%$. Wpływ na jego wartość ma czas uprzedniego leczenia za pomocą TKI (u chorych leczonych krócej lub dłużej niż 8 lat wynosi odpowiednio $74 \%$ i 53\%) oraz okres pozostawania w $\mathrm{MR}^{4}$ przed odstawieniem TKI (odpowiednio $68 \%$ i $53 \%$ w przypadku utrzymywania się jej krócej lub dłużej niż 5 lat) [9].

W badaniu STIM2 (Stop IMatinib2) kryteria kwalifikacji i definicja utraty odpowiedzi molekularnej (potwierdzona utrata CMR) były takie same jak w badaniu STIM1, jednak ponowne leczenie imatynibem wdrażano dopiero $z$ chwilą utraty MMR. Powyższą decyzję oparto na obserwacji wskazującej, że u około $30 \%$ chorych dochodzi do fluktuacji ilości wykrywalnego transkryptu $B C R / A B L 1$, niewzrastającego jednak powyżej $0,1 \%$ 
i niezwiązanego $z$ pełnoobjawowym nawrotem CML. Nawrót molekularny odnotowano w 48 przypadkach (38,5\%); u większości chorych doszło do niego w pierwszych 6 miesięcach, a u 3 pacjentów — między 6. a 12. miesiącem po odstawieniu TKI. Po roku obserwacji 76 chorych (61\%) utrzymało MMR, co było jednoznaczne $z$ odpowiedzią wolną od konieczności wdrożenia terapii (TRF, treatment-free response) [10].

W badaniu TWISTER, w przebiegu którego stosowano bardzo zbliżone kryteria kwalifikacji, nawrotu molekularnego i ponownego wdrożenia leczenia, odsetek TFR po 24 miesiącach od odstawienia imatynibu wynosił 47,1\%. Większość nawrotów wystąpiła w pierwszych 4 miesiącach od odstawienia imatynibu; nie odnotowano żadnego nawrotu 27 miesięcy po odstawieniu leku [11]. W innym badaniu o tych samych kryteriach, które obejmowało 94 pacjentów z CMR trwającą nieprzerwanie przez conajmniej rok, po 11,6 miesiąca obserwacji prawdopodobieństwo 12-miesięcznego TFR wynosiło $65,3 \% \pm 5,3 \%$. W przypadku 29 chorych, którzy utracili MMR, po powrocie do leczenia imatynibem odpowiedź ta została odzyskana u wszystkich, natomiast CMR uzyskano ponownie u 16 pacjentów. Analiza jednowariantowa ujawniła, że największe znaczenie dla uzyskania 12-miesięcznej TFR ma długość trwania leczenia imatynibem i okres CMR uzyskanej przed odstawieniem imatynibu [12].

W prospektywnym badaniu DADI (DAsatinib Discontinuation) podejmowano próbę odstawienia dazatynibu u chorych z CMR, u których odpowiedź utrzymywała się nieprzerwanie przez przynajmniej rok. Badaniem objęto 63 chorych, którzy otrzymywali dazatynib jako leczenie II rzutu (13 z powodu oporności na imatynib, $36 \mathrm{z}$ powodu nietolerancji, u 12 stosowano wcześniej interferon alfa [IFN $\alpha$ ], u 4 nilotynib, u 1 IFN $\alpha$ i nilotynib). Spośród 62 chorych, którzy osiągnęli 6-miesięczny okres obserwacji po odstawieniu dazatynibu, u 30 utrzymywała się CMR. Obliczone na podstawie krzywej Kaplana-Meiera 6-miesięczne TFR wynosiło $48,3 \%$. Ponowne wdrożenie dazatynibu u chorych $z$ nawrotem molekularnym doprowadziło u 28 spośród 29 ocenianych pacjentów (97\%) do odzyskania CMR w czasie 3 miesięcy. U chorego, który nie odzyskał CMR, także doszło do znacznej redukcji ilości transkryptu $B C R / A B L 1$ [13].

Wyniki powyższych badań wskazują, że u znacznej części chorych na CML, którzy uzyskali w toku leczenia za pomocą TKI bardzo głęboką i długotrwałą odpowiedź molekularną, możliwe jest uzyskanie trwałej TFR mimo obecności resztkowej populacji komórek z transkryptem $B C R / A B L 1$. Odstawienie TKI w tej grupie chorych jest bezpieczne, gdyż przywrócenie leczenia u pacjentów $z$ nawrotem powoduje odzyskanie utraconej odpowiedzi molekularnej u prawie wszystkich chorych, a zaprzestanie leczenia nie było przyczyną progresji CML u żadnego chorego.

\section{Białaczkowe komórki macierzyste}

Jakkolwiek obiecujące są wyniki badań dotyczących odstawienia TKI, to nawroty molekularne po odstawieniu leku w dużej grupie chorych wskazują, że monoterapia TKI często nie jest w stanie całkowicie wyeliminować komórek białaczkowych, a co za tym idzie - trwale wyleczyć. Dlatego na polu badań dotyczących CML wiele uwagi w ostatnich latach poświęcono możliwości eradykacji choroby resztkowej poprzez eliminację macierzystych komórek białaczkowych (LSC, leukemic stem cells). W 2013 roku ukazała się publikacja Ahmeda i van Ettena [14], w której podsumowano dotychczasowe rezultaty. Komórki progenitorowe $B C R / A B L 1+$ CD34+ izolowano u pacjentów, którzy w trakcie leczenia TKI uzyskali MMR, a nawet CMR, co dowodzi, że ich przeżycie nie jest całkowicie zależne od onkogenu. Zidentyfikowano kilka szlaków przekaźnictwa sygnałów wewnątrzkomórkowych, których zahamowanie może umożliwić eliminację LSC; należą do nich JAK-STAT, PI3K/AKT/mTOR, $\mathrm{WNT} / \beta$-catenina oraz szlak Hedgehog. Inne potencjalne podejście terapeutyczne zakłada stymulację układu odpornościowego do eliminacji LSC za pomocą IFN $\alpha$ bądź szczepionek $z$ antygenami peptydowymi BCR/ABL1 lub innych białek ulegających zwiększonej ekspresji u chorych na CML. Do eliminacji LSC mogłyby również prowadzić manipulacje $\mathrm{w}$ obrębie mikrośrodowiska niszy szpikowej, poprzez stymulację cyklu komórkowego LSC pozostających w fazie $\mathrm{G}_{0}$, hamowanie przekaźnictwa sygnałów dla cytokin produkowanych przez komórki stromalne szpiku kostnego (granulocytarny lub granulocytarno-makrofagowy czynnik wzrostu, interleukina 6) lub interakcji adhezyjnych LSC $z$ niszą szpikową [14]. Wiele $z$ tych teoretycznych możliwości jest już testowanych w toczących się badaniach klinicznych.

\section{Czynniki rokownicze i predykcyjne}

Możliwość prognozowania przebiegu CML i określenia kategorii ryzyka u chorych na CML w chwili rozpoznania choroby lub jak najwcześniej $\mathrm{w}$ toku jej leczenia jest bardzo ważnym problemem, 
któremu poświęcono wiele uwagi w ostatnich latach. W 2011 roku ukazała się publikacja prezentująca wskaźnik prognostyczny EUTOS opracowany na podstawie analizy przebiegu leczenia imatynibem 2060 chorych na nowo rozpoznaną CP-CML. Wskaźnik ten pozwala ocenić prawdopodobieństwo uzyskania CCyR po 18 miesiącach leczenia za pomocą TKI; odpowiedź ta dobrze koreluje $z$ przeżyciem. Formuła EUTOS opiera się na pomiarze liczby bazofili we krwi obwodowej oraz wielkości śledziony $\mathrm{w}$ badaniu przedmiotowym przed rozpoczęciem leczenia $(7 \times$ odsetek [\%] bazofili we krwi obwodowej $+4 \times$ maksymalna wielkość śledziony [cm] poniżej łuku żebrowego). Na jej podstawie wyodrębniono grupę pacjentów o wysokim i niskim ryzyku niepomyślnego przebiegu choroby (punkt odcięcia odpowiednio $>87 \mathrm{i} \leq 87$ ). We wspomnianym badaniu dodatnia wartość predykcyjna (PPV, positive predictive value) wskaźnika EUTOS dla nieosiągnięcia CCyR po 18 miesiącach wyniosła $34 \%$. Chorych $z$ grupy niskiego ryzyka cechowało istotnie lepsze 5-letnie PFS niż pacjentów $z$ grupy ryzyka wysokiego $(90 \%$ v. $82 \%$; $\mathrm{p}=0,006)[15]$.

W swojej publikacji Fabarius i wsp. [16] wskazali na wagę dodatkowych zaburzeń cytogenetycznych kariotypu (ACA, additional chromosome aberrations) wykrywanych u chorych na CML w chwili rozpoznania. Spośród 1151 chorych translokację wariantową $\mathrm{t}(\mathrm{v} ; 22)$ stwierdzono u 69 pacjentów, a ACA - u 79 (6,9\%). Aberracje obserwowane u chorych z ACA obejmowały utratę chromosomu $\mathrm{Y}(\mathrm{n}=38 ; 3,3 \%)$, u $16(1,4 \%)$ chorych wykryto aberracje o typie major-route (dodatkowy chromosom $\mathrm{Ph}$, trisomię 8 , izochromosom $17 \mathrm{q}$ i trisomię 19 pary chromosomów), a u 25 - aberracje minor-route (wszystkie pozostałe). Mediana czasu obserwacji wynosiła 5,3 roku; stwierdzono negatywny wpływ ACA typu major-route na przebieg choroby. Czas do osiągnięcia CCyR i MMR był istotnie dłuższy, a PFS i OS — krótszy ( $p<0,001)$ niż u chorych $z$ typową translokacją $\mathrm{t}(9 ; 22)$. Potwierdzono jednocześnie wcześniejsze obserwacje wskazujące, że translokacja wariantowa $\mathrm{t}(\mathrm{v} ; 22)$, [der(9)], utrata chromosomu Y i obecność aberracji minor-route nie wpływają na przebieg choroby ani rokowanie u chorych na CML [16]. Stopień redukcji ilości transkryptu $B C R / A B L 1$ w ilościowym badaniu reakcji łańcuchowej polimerazy (RQ-PCR, real-time quantitative polymerase chain reaction) po 3 i 6 miesiącach leczenia za pomocą TKI stał się nowym czynnikiem prognostycznym określającym szanse chorych na uzyskanie długotrwałego przeżycia wolnego od zdarzeń niepożądanych (EFS, event-free survival), PFS i OS. Chorzy, u których doszło do redukcji ilości transkryptu $B C R-A B L 1$ do $10 \%$ lub mniej po 3 miesiącach i do $1 \%$ lub mniej po 6 miesiącach leczenia imatynibem uzyskują 8-letnie EFS, PFS i OS w znamiennie większym odsetku niż pacjenci bez takiej redukcji [17].

Wyniki te potwierdzono w badaniu CML Study IV; pacjenci, którzy uzyskali po 3 miesiącach leczenia imatynibem przynajmniej częściową odpowiedź cytogenetyczną (PCyR, partial cytogenetic response) (odpowiadającą redukcji ilości transkryptu $B C R$ $-A B L 1$ do $\leq 10 \%$ ), a po 6 miesiącach $-\mathrm{CCyR}$ (odpowiadającą redukcji ilości transkryptu $B C R$ $-A B L 1$ do $\leq 1 \%)$ w większym odsetku osiągali 5-letnie PFS i OS [18]. Zależność między stopniem redukcji ilości transkryptu $B C R / A B L 1$ po 3 miesiącach a szansą na osiagnięcie głębokiej odpowiedzi molekularnej w toku dalszego leczenia odnotowano także w przebiegu badań służących porównaniu skuteczności imatynibu i 2GTKI stosowanych $\mathrm{w}$ terapii pierwszego wyboru.

Redukcja ilości transkryptu $B C R / A B L 1$ w badaniu RQ-PCR do $10 \%$ lub mniej po 3 miesiącach leczenia za pomocą TKI zwiększa szansę nie tylko na uzyskanie $\mathrm{MR}^{4,5}$, ale również lepszych odsetków PFS i OS. Odsetki te w przypadku leczenia imatynibem u chorych $\mathrm{z}$ ilością transkryptu do $10 \%$ lub mniej lub ponad $10 \%$ po 3 miesiącach leczenia wynoszą odpowiednio $98 \%$ i 83\%, w przypadku leczenia nilotynibem w tym samym badaniu (ENESTnd) [19] - 95\% i 83\%, a w przypadku leczenia dazatynibem w badaniu DASISION [20] - 93\% i 68\%. Opisane wyżej prawidłowości występują niezależnie od przyjmowanego TKI, jednak znaczną redukcję ilości kopii transkryptu po pierwszych 3 miesiącach terapii w każdym $z$ tych badań znamiennie częściej uzyskują chorzy otrzymujący 2GTKI. Podobne znaczenie rokownicze ma redukcja ilości transkryptu po 6 miesiącach leczenia TKI. Istotnie większe odsetki PFS i OS po 3 latach obserwacji w badaniu DASISION uzyskują chorzy $z$ redukcją do poniżej $1 \%$. Ponadto pacjenci z ilością kopii transkryptu powyżej $1 \% \mathrm{w} 6$. miesiącu terapii TKI są obciążeni istotnie wyższym ryzykiem transformacji CML w bardziej zaawansowane fazy choroby [20].

Innym nowym, wcześnie ocenianym biomarkerem molekularnym jest określenie czasu potrzebnego na 50-procentową redukcję ilości transkryptu $B C R / A B L 1$ u indywidualnego chorego (HT, halving time). Pacjenci, u których czas ten nie przekracza 11 dni, mają istotnie statystycznie większe szanse na osiągnięcie MMR po 12 miesiącach leczenia, $\mathrm{MR}^{4,5}$ oraz 4-letniego przeżycia wolnego od niepowodzenia terapii (FFS, failure-free survival). 
W jednowariantowej i wielowariantowej analizie regresji przeprowadzonej u 521 chorych tylko wskaźnik Sokala i HT zbadany po pierwszym miesiącu były czynnikami niezależnie prognozującymi MMR, MR ${ }^{4.5}$ i FFS. Czas potrzebny na 50-procentową redukcję ilości transkryptu $B C R / A B L 1$ okazał się równie silnym czynnikiem rokowniczym jak wskaźnik Sokala; pacjenci z grupy wysokiego ryzyka według Sokala, u których HT wynosił nie więcej niż $11 \mathrm{dni}$, mieli porównywalne szanse na uzyskanie MMR po 12 miesiącach leczenia, osiągnięcie $\mathrm{MR}^{4,5} \mathrm{i}$ wysokiego odsetka 4-letniego FFS jak chorzy $z$ grupy niskiego ryzyka. Natomiast u pacjentów cechujących się pośrednim i niskim ryzykiem według Sokala $z$ HT ponad 29 dni odsetki uzyskiwanych odpowiedzi (MMR po 12 miesiącach leczenia, $\mathrm{MR}^{4.5} \mathrm{i}$ FFS) były znacznie mniejsze [21].

\section{Zalecenia dotyczące leczenia chorych na CML}

Wprowadzenie do standardu leczenia chorych na CML kolejnych generacji TKI wymusiły konieczność uaktualnienia zaleceń w tym zakresie; w 2013 roku opublikowano zalecenia PALG (Polish Adult Leukemia Group) [22] i prawie jednocześnie ukazały się zalecenia opracowane przez ekspertów ELN [23]. Brzmienie obu dokumentów w zakresie definicji odpowiedzi optymalnej na leczenie TKI jest identyczne. Zasadnicza różnica w obu cytowanych publikacjach tkwi w interpretacji braku redukcji ilości transkryptu $B C R / A B L 1$ do poziomu poniżej $10 \%$ po pierwszych 3 miesiącach leczenia za pomocą TKI. Według zaleceń PALG w takim przypadku - jeżeli wynik potwierdzono drugim rezultatem badania molekularnego lub $\mathrm{w}$ badaniu cytogenetycznym - należy rozpoznać niepowodzenie leczenia i dokonać jego modyfikacji (najpóźniej w 6. miesiącu), natomiast eksperci ELN interpretują taki wynik jako warunek ostrzeżenia i zalecają modyfikację leczenia dopiero $\mathrm{w}$ razie braku redukcji ilości transkryptu $B C R / A B L 1$ do poziomu poniżej $10 \%$ po 6 miesiącach leczenia. Druga różnica polega na interpretacji nieuzyskania MMR w toku leczenia TKI; według zaleceń PALG brak osiągnięcia MMR w 12. miesiącu leczenia za pomocą TKI powinno się uznać za niepowodzenie leczenia, natomiast według zaleceń ELN - za ostrzeżenie. Nowe wyniki publikowanych badań wskazują, że opóźnienie decyzji o zmianie leczenia do 6. miesiąca w takiej sytuacji może się wiązać z mniejszą szansą zapobieżenia progresji CML do AP i BP, a brak osiąnnięcia MMR w toku leczenia wiąże się $z$ gorszym rokowaniem.

\section{Leczenie chorych na CML a wtórne nowotwory}

Długotrwałemu leczeniu chorych na CML za pomocą TKI towarzyszy ryzyko zachorowania na inny nowotwór. Nowe światło na to zagadnienie rzuciła niedawno opublikowana analiza danych pochodzących ze szwedzkiego rejestru nowotworów obejmującego 868 chorych na CML obserwowanych w latach 2002-2011. Wykazano w niej, że standaryzowany wskaźnik zapadalności (SIR, standardized incidence ratio), który wyliczono jako stosunek liczby przypadków obserwowanych do liczby przypadków spodziewanych w populacji chorych na CML wynosi 1,5 (95-proc. przedział ufności 1,13-1,99). Jest on wyższy u kobiet niż u mężczyzn (odpowiednio 1,8 i 1,3) oraz u chorych $\mathrm{w}$ wieku poniżej 60 lat w porównaniu $\mathrm{z}$ pozostałymi (odpowiednio 1,9 i 1,5). Nowotwory przewodu pokarmowego, nosa i gardła (różnice między liczbą przypadków obserwowanych a spodziewanych istotne statystycznie) należą do najczęściej występujących u chorych na CML leczonych za pomocą TKI [24].

\section{Podsumowanie}

Celem nowoczesnej strategii leczenia chorych na CML, znajdującej poparcie w wynikach badań klinicznych prowadzonych w ostatnich latach, jest jak najszybsze doprowadzenie do bardzo głębokiej odpowiedzi molekularnej $\left(\mathrm{MR}^{4}, \mathrm{MR}^{4,5}\right)$, która umożliwia zaprzestanie leczenia i uzyskanie długotrwałej TFR, a nawet wyleczenia. Wciąż jednak, mimo możliwości skutecznej kontroli choroby u większości pacjentów, nie jest jasne, czy zastosowanie TKI może prowadzić do wyleczenia. Trwają poszukiwania biomarkerów, które mogłyby stanowić czynnik do prognozowania możliwości skutecznego odstawienia leczenia, oraz takich, które mogłyby się stać celem terapii ukierunkowanej służącej eliminacji LSC — źródła nawrotu choroby.

\section{Piśmiennictwo}

1. Deininger M., O’Brien S.G., Guilhot F. i wsp. International Randomized Study of Interferon Vs STI571 (IRIS) 8-Year Follow up: sustained survival and low risk for progression or events in patients with newly diagnosed chronic myeloid leukemia in chronic phase (CML-CP) treated with imatinib. Blood 2009; 119: abstrakt 1126.

2. Jabbour E., Kantarjian H.M., Saglio G. i wsp. Early response with dasatinib or imatinib in chronic myeloid leukemia: 3-year follow-up from a randomized phase 3 trial (DASISION) Blood 2014; 123: 494-500. 
3. Kantarjian H.M., Hochhaus A., Saglio G. i wsp. Nilotinib versus imatinib for the treatment of patients with newly diagnosed chronic phase, Philadelphia chromosome-positive, chronic myeloid leukaemia: 24-month minimum follow-up of the phase 3 randomised ENESTnd trial. Lancet Oncol. 2011; 12: 841-851.

4. O’Brien S., Hedgley C., Adams S. i wsp. Spirit 2: an NCRI randomised study comparing dasatinib with imatinib in patients with newly diagnosed CML. Blood 2014; 124: abstrakt 517.

5. Cortes J.E., Kim D.W., Kantarjian H.M. i wsp. Bosutinib versus imatinib in newly diagnosed chronic-phase chronic myeloid leukemia: results from the BELA trial. J. Clin. Oncol. 2012; 30: 3486-3492.

6. Cortes J.E., Kantarjian H.M., Shah N. i wsp. Ponatinib in refractory Philadelphia-positve leukemias. N. Engl. J. Med. 2012; 367: 2075-2088.

7. Lipton J.H., Chuah C., Guerci-Bresler A. i wsp. Epic: a phase 3 trial of ponatinib compared with imatinib in patients with newly diagnosed chronic myeloid leukemia in chronic phase (CP-CML). Blood 2014; 124: abstrakt 519.

8. Mahon F.X., Rea D., Guilhot J. i wsp. Discontinuation of imatinib in patients with chronic myeloid leukaemia who have maintained complete molecular remission for at least 2 years: the prospective, multicentre stop imatinib (STIM) trial. Lancet Oncol. 2010; 11: 1029-1035.

9. Mahon F.X., Richter J., Guilhot J. i wsp. Interim Analysis of a Pan European Stop Tyrosine Kinase Inhibitor Trial in Chronic Myeloid Leukemia: the EURO-SKI study. Blood 2014; 124: abstrakt 151.

10. Mahon F.X., Nicolini F.E., Noël M.P. i wsp. Preliminary report of the STIM2 study: a multicenter stop imatinib trial for chronic phase chronic myeloid leukemia de novo patients on imatinib. Blood 2013; 123: abstrakt 654.

11. Ross D.M., Branford S., Seymour J.F. i wsp. Safety and efficacy of imatinib cessation for CML patients with stable undetectable minimal residual disease: results from the TWISTER study. Blood 2013; 122: 515-522.

12. Oh Y L.S., Choi S. [trzeci autor?] i wsp. Discontinuation of BCR-ABL1 tyrosine kinase inhibitor in CML patients with undetectable molecular residual disease for at least 1 year: including updated data from KIDS study. 18th Congress of the European Hematology Association (Meeting Abstracts). Blood 2013; 123 : abstrakt 4401.

13. Kimura S., Imagawa J., Okada M. i wsp. Discontinuation of dasatinib in patients with $\mathrm{cml}$ who have maintained complete mo- lecular response for at least one year: results from a prospective discontinuation (DADI) trial. Hematologica 2014; 124: abstrakt 3468.

14. Ahmed W., van Etten R.A. Alternative approaches to eradicating the malignant clone in chronic myeloid leukemia: tyrosine-kinase inhibitor combinations and beyond. Hematology Am. Soc. Hematol. Educ. Program 2013; 2013: 189-200.

15. Hasford J., Baccarani M., Hoffmann V. i wsp. Predicting complete cytogenetic response and subsequent progression-free survival in 2060 patients with CML on imatinib treatment: the EUTOS score. Blood 2011; 118: 686-692.

16. Fabarius A., Leitner A., Hochhaus A. i wsp. Impact of additional cytogenetic aberrations at diagnosis on prognosis of CML: long-term observation of 1151 patients from the randomized CML Study IV. Blood 2011; 118: 6760-6768.

17. Marin D., Hedgley C., Clark R.E. i wsp. Predictive value of early molecular response in patients with chronic myeloid leukemia treated with first-line dasatinib. Blood 2012; 120: 291-294.

18. Hanfstein B., Mueller M.C., Hehlmann R. i wsp. Early molecular and cytogenetic response is predictive for long-term progression-free and overall survival in chronic myeloid leukemia (CML). Leukemia 2012; 26: 2096-2102.

19. Hughes T.P., Saglio G., Kantarjian H.M. i wsp. Early molecular response predicts outcomes in patients with chronic myeloid leukemia in chronic phase treated with frontline nilotinib or imatinib. Blood 2014; 123: 1353-1360.

20. 20. Jabbour E., Kantarjian H.M., Saglio P. i wsp. Early response with dasatinib or imatinib in chronic myeloid leukemia: 3-year follow-up from a randomized phase 3 trial (DASISION). Blood 2014; 123: 494-500.

21. Branford S., Yeung D.T., Parker W.T. i wsp. Prognosis for patients with CML and $>10 \%$ BCR-ABL1 after 3 months of imatinib depends on the rate of BCR-ABL1 decline. Blood 2014; 124: 511-518.

22. Sacha T., Lewandowski K., Hellmann A. i wsp. Rekomendacje PALG dotyczące diagnostyki i leczenia przewlekłej białaczki szpikowej w 2013 r. Acta Hematol. Pol. 2013; 44: 345-362.

23. Baccarani M., Deininger M.W., Rosti G. European LeukemiaNet recommendations for the management of chronic myeloid leukemia: 2013. Blood 2013; 122: 872-884.

24. Gunnarsson N., Leif S., Höglund M., i wsp. Second malignancies following treatment of chronic myeloid leukemia in the tyrosine kinase inhibitor era. Blood 2014; 124: abstrakt 154. 